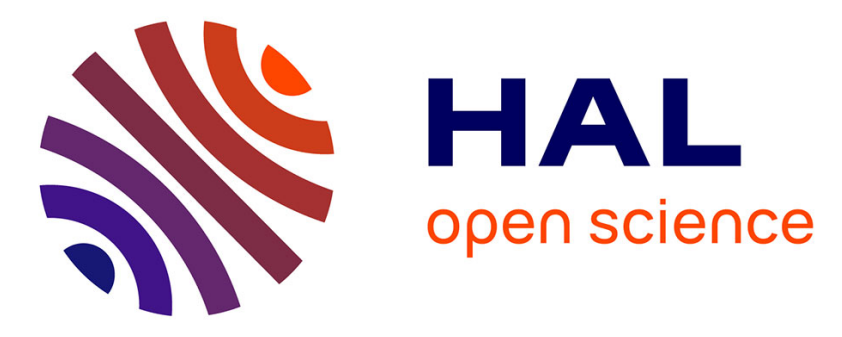

\title{
FPGA based fault-tolerant control on an interleaved DC/DC boost converter for fuel cell electric vehicle applications
}

Damien Guilbert, Michael Guarisco, Arnaud Gaillard, Abdoul Diaye, Abdesslem Djerdir

\section{To cite this version:}

Damien Guilbert, Michael Guarisco, Arnaud Gaillard, Abdoul Diaye, Abdesslem Djerdir. FPGA based fault-tolerant control on an interleaved DC/DC boost converter for fuel cell electric vehicle applications. International Journal of Hydrogen Energy, 2015, 40 (45), pp.15815-15822. 10.1016/j.ijhydene.2015.03.124 . hal-02868264

\section{HAL Id: hal-02868264 \\ https://hal.science/hal-02868264}

Submitted on 21 Oct 2021

HAL is a multi-disciplinary open access archive for the deposit and dissemination of scientific research documents, whether they are published or not. The documents may come from teaching and research institutions in France or abroad, or from public or private research centers.
L'archive ouverte pluridisciplinaire HAL, est destinée au dépôt et à la diffusion de documents scientifiques de niveau recherche, publiés ou non, émanant des établissements d'enseignement et de recherche français ou étrangers, des laboratoires publics ou privés. 


\title{
FPGA based fault-tolerant control on an interleaved DC/DC boost converter for fuel cell electric vehicle applications
}

\author{
Damien Guilbert ${ }^{a, c, *}$, Michael Guarisco ${ }^{b}$, Arnaud Gaillard ${ }^{a, c}$, \\ Abdoul N'Diaye ${ }^{b, c}$, Abdesslem Djerdir ${ }^{b, c}$ \\ a FEMTO-ST Institute, Energy Department (UMR CNRS 6174), UBFC/UTBM, 90010 Belfort, Cedex, France \\ ${ }^{\mathrm{b}}$ IRTES-SET, UBFC/UTBM, 90010 Belfort, Cedex, France \\ ${ }^{\text {c }}$ Fuel Cell Laboratory (FCLAB, FR CNRS 3539), 90010 Belfort, Cedex, France
}

\begin{abstract}
In recent years, the effects of high-frequency current ripple coming from DC/DC converters on Proton Exchange Membrane Fuel Cell (PEMFC) have gained a growing interest from the international scientific community. Currently, the durability is one of the major technical challenges to PEMFC commercialization. Basing on the existing literature, the high-frequency current ripple leads up to longterm degradations on PEMFC, particularly on its lifetime. Accordingly, in order to enhance the PEMFC lifetime, new DC/DC converter topologies have been developed, such as Interleaved DC/DC Boost Converter (IBC). Despite this topology can minimize drastically the current ripple, the loss of one leg in case of power switch fault leads up to the drastic increasing of the current ripple and consequently long-term degradations on the PEMFC. In order to cope with this issue, solutions have to be developed. Within the framework of this research work, an efficient Fault-Tolerant Control (FTC) implemented on an FPGA board has been developed to solve this issue. The latter consists in changing the PWM gate control signal according to the faulty leg given by a fault detection algorithm. The obtained experimental results between a PEMFC and an IBC to-pology allows demonstrating the ability of the FTC to reduce drastically the current ripple in case of power switch faults.
\end{abstract}

\section{Introduction}

Recently (i.e. 2011) [1], a survey on the industry regarding the reliability of power converters was carried out in order to determine the needs of the industry and also reliability expectations. According to this survey, power switches ranked the most delicate components. Furthermore, this study has allowed emphasizing the causes of the main stresses of power switches, which are:

\footnotetext{
* Corresponding author. FEMTO-ST Institute, Energy Department (UMR CNRS 6174), UBFC/UTBM, 90010 Belfort, Cedex, France. Tel.: +33 384583629; fax: +33 384583636 .

E-mail addresses: damien.guilbert@utbm.fr (D. Guilbert), michael.guarisco@utbm.fr (M. Guarisco), arnaud.gaillard@utbm.fr (A. Gaillard), abdoul-ousman.n-diaye@utbm.fr (A. N'Diaye), abdesslem.djerdir@utbm.fr (A. Djerdir).
} 


\section{Nomenclature}

$\begin{array}{ll}\text { Acronyms } & \\ \text { CCM } & \text { Continuous Conduction Mode } \\ \text { ECU } & \text { Electronic Control Unit } \\ \text { FC } & \text { Fuel Cell } \\ \text { FCEV } & \text { Fuel Cell Electric Vehicle } \\ \text { FIBC } & \text { Floating Interleaved Boost Converter } \\ \text { FPGA } & \text { Field Programmable Gate Array } \\ \text { FTC } & \text { Fault-Tolerant Control } \\ \text { IBC } & \text { Interleaved Boost Converter } \\ \text { OCF } & \text { Open Circuit Fault } \\ \text { PEMFC } & \text { Proton Exchange Membrane Fuel Cell } \\ \text { SCF } & \text { Short Circuit Fault } \\ \text { VHDL } & \text { VHSIC Hardware Description Language }\end{array}$

1 Environment;

2 Transients (load, source, faults);

3 Heavy loads.

Due to the importance of power switches, many researchers have published many papers concerning faultdetection algorithm for power converters, including DC/DC converters [2-13]. The most common failures in power switch are Open Circuit Faults (OCFs), gating faults, and Short-Circuit Faults (SCFs) [14]. Furthermore, OCFs can be a consequence of SCFs if and only if the fuse melts before the short-circuit damages the system [15]. These faults may occur due to external or internal events such as incorrect gate voltage, driver failure, lifting of bonding wires due to thermal cycling, electrical over stress (i.e. voltage or current) [14]. In this study, only OCFs are considered.

Once the fault has been detected, DC/DC converter stop must be avoided. In order to ensure a continuity of service and/or reduce the undesirable effects of degraded operating modes, a fault-tolerant DC/DC converter topology or/and a Fault-Tolerant Control (FTC) must be used. Starting from the existing literature [16], only $36 \%$ of papers present a fault detection algorithm combined with an FTC. Different approaches have been introduced in the literature for faulttolerant DC/DC converters. Some of them are based on dynamic redundancy with a control reconfiguration [2-9] representing $67 \%$ of the papers with FTC; whereas others use control reconfiguration without dynamic redundancy [10-12] (i.e. $25 \%$ of the papers) or modularity [13] (i.e. $8 \%$ of the papers). Generally, control reconfiguration without dynamic redundancy is preferred for automotive applications. Indeed, the use of dynamic redundancy goes back to increase the cost and the volume of the DC/DC converter which is not fit for automotive applications [17]. Additionally, $48 \%$ of the papers present a detection algorithm for OCFs; whereas $45 \%$ of the papers present a detection algorithm for OCFs and SCFs.

By comparison, fault-tolerance in Fuel Cells (FCs) has been studied through many papers available in the literature [18-29]. The major parts of these papers propose faulttolerant FC system in order to ensure a continuity of service in case of failures. However, these papers do not present FTC to minimize the effects of degraded operating mode on the FC.
Within the framework of this research work, an Interleaved Boost Converter (IBC) is used in order to meet the Fuel Cell Electric Vehicle (FCEV) requirements in terms of compactness, efficiency, FC current ripple and reliability in case of power switch faults [17]. Despite the IBC continues to supply power to the load without any interruption in case of power switch faults, the loss of one leg leads up to the drastic increase of the FC current ripple. According to the existing literature [30-32], the high-frequency current ripple with a high peak-to-peak value could lead up to long-term degradations, particularly with the decrease of the active surface of platinum from catalysts. For this reason, it is crucial to apply an FTC in order to reduce drastically these degradations. Concerning the three-leg IBC topology, the FTC consists in changing the PWM gate control signal according to the faulty leg. Indeed, the FTC strategy depends strongly on the faulty leg. An unfit control reconfiguration could have undesirable effects on the system such as the FC current ripple increasing [17].

This paper is divided into 4 sections. After the introduction presenting a review on this topic, section Architecture of FCEV and IBC topology presents the architecture of the FCEV and the IBC topology. Then, in section Developed fault-tolerant control, the developed FTC is explained in details. Finally, the section Experimental test bench and results presents the experimental setup carried out for this work and the obtained experimental results. Besides, a discussion focused on a review of previous works regarding the minimization of current ripple and the advantage of the developed FTC on an FPGA board is provided.

\section{Architecture of FCEV and IBC topology}

\section{Presentation of the architecture of FCEV}

The powertrain of an FCEV needs a great deal of components as it is demonstrated in Fig. 1, among which the Proton Exchange Membrane Fuel cell (PEMFC), DC/DC and DC/AC converters, electrical motors and finally an auxiliary power unit (e.g. batteries or Supercapacitors). In this case under study, high-voltage batteries are used to assist the propulsion of the vehicle during transients and to absorb the kinetic energy during regenerative braking. Within the framework of this research work, only the PEMFC and DC/DC converters are considered.

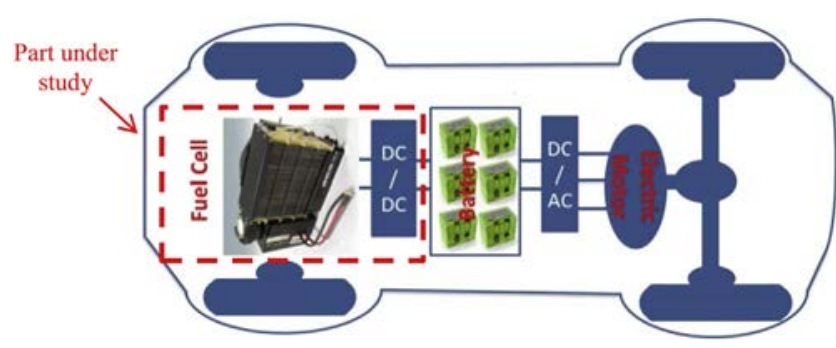

Fig. 1 - Example of architecture of the powertrain of the FCEV [33]. 
Presentation and advantages of the IBC topology

Starting from challenging issues in FCEV applications [17], it has been chosen to focus our present study on an IBC topology. The schematic representation of this topology combined with a PEMFC is depicted in Fig. 2. This topology presents several advantages compared with others topologies of DC/DC converters for FCEV applications [34], including compactness, high efficiency, reduced FC current ripple and adaptability for degraded operating mode in case of power switch faults. The choice of the number of legs (i.e. $\mathrm{N}=3$ ) is justified by a compromise between volume of inductors, efficiency, input current ripple, redundancy and cost [17].

Due to the architecture of the 3-leg IBC topology, if a power switch fault occurred on one leg, this could be compensated by the healthy legs. As a result, the IBC topology continues to supply power to the load without any interruption [3].

In order to satisfy the fault tolerance requirements, fuses (F1, F2, F3) have been added in series with each power switch, as illustrated in Fig. 2. The fuses allow isolating faulty leg in case of SCFs. Furthermore, the PEMFC has to be electrically protected (e.g. addition of a fuse series connected with the IBC) against possible SCF [17]. In order to make easier the study, the rest of FCEV powertrain is considered like a resistive load.

\section{Developed fault-tolerant control}

\section{Fault-tolerant control principle}

As it was mentioned in a previous work [17], the concept of interleaving of the IBC topology is guaranteed by the phase shifted control of the three switches (S1, S2, S3). In the case under study, each PWM gate control signal is shifted from each other with a time delay of Ts/3, where Ts is the switching period of the IBC topology. Under a degraded mode, the PWM gate control signals of the healthy power switch continue to be shifted from each other with a time delay of $\mathrm{Ts} / 3$. As a result, the FC current ripple increases compared to a healthy mode due to the OCF as depicted in Fig. 3.

As it was highlighted in Ref. [17], once the OCF occurs, the healthy legs allow compensating the faulty leg in order to avoid any power interruption to the load. However, the loss of one phase leads up to the increasing of the other inductor phase currents (i.e. the healthy leg current increase of $50 \%$ compared to a healthy mode), creating consequently

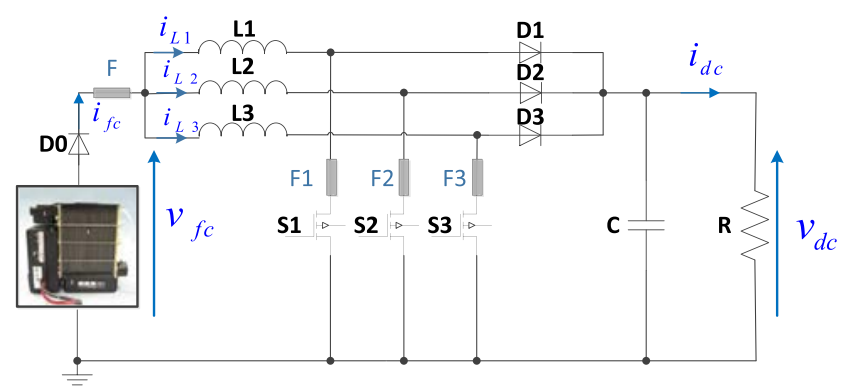

Fig. 2 - Pemfc and 3-leg IBC. additional electrical stresses, particularly on the power switch and inductive component. Accordingly, in order to guarantee the reliability of the IBC topology in case of power switch fault, the power switches should be oversized. Indeed, the electrical over stress (i.e. current) could lead up to power switch failures $[14,17]$. Regarding the inductors, their sizing must be optimized in order to minimize their volume and weight, particularly for automotive applications.

Over the last decade, many researchers have investigated the effect of low and high-frequency current ripple coming from power converters on PEMFCs. Although the impact on the PEMFC lifetime is so far not well understood, some observations have been already reported in the literature. Generally, DC/DC converters generate high-frequency current ripple (i.e. $>10 \mathrm{kHz}$ ); whereas DC/AC converters produce lowfrequency current ripple (i.e. $100-120 \mathrm{~Hz}$ ) depending strongly on the load and the type of DC/AC converter used [17]. Up to the present, the effects of high-frequency current ripple have been analyzed using an electronic load combined with a signal generator, allowing simulating FC current ripple coming from DC/DC converters. However, the use of a signal generator limits the scope of investigation up to a frequency current ripple equal to $10 \mathrm{kHz}$. The use of a DC/DC converter could broaden the scope of investigation for FC current ripple frequencies higher than $10 \mathrm{kHz}[17,35]$; where the new topologies of DC/DC converter (e.g. topologies including softswitching and/or Silicone Carbide (SiC) semiconductors) for PEMFC applications operate. This will allow having a better understanding of the real impact of high-frequency current ripples on PEMFC lifetime; which is one of the major challenges to FC commercialization [36]. According to a brief review of this topic of emerging interest [17], high-frequency current ripple can lead up to long-term degradations, particularly with the decrease of the active surface of platinum from catalysts.

It is important to apply an FTC once the fault has been detected in order to reduce drastically the degradations introduced in the literature [30-32]. Concerning the 3-leg IBC topology, the FTC consists in changing the PWM gate control signal according to the faulty leg given by a fault detection algorithm [17]. Indeed, the FTC depends strongly on the faulty leg. An unfit control reconfiguration could have undesirable

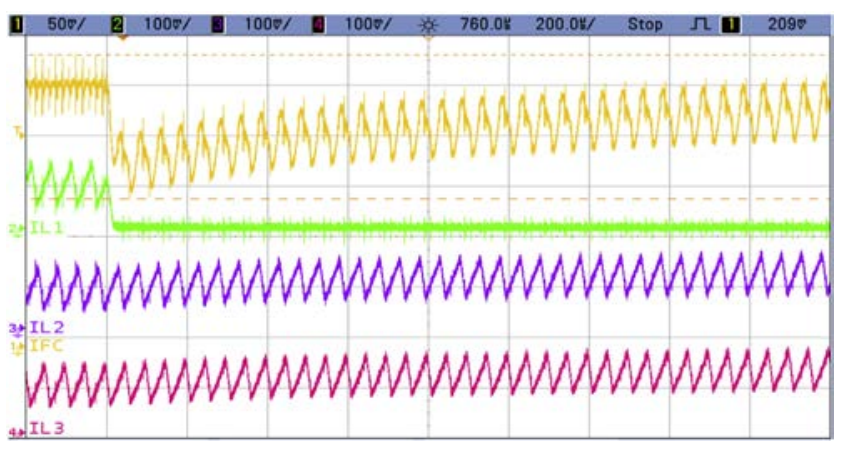

Fig. 3 - FC current ripple increasing after an OCF, obtained for $D=0.72$ : channel 1: FC current [5A/div], channel 2: leg 1 current (faulty) [10A/div], channel 3: leg 2 current [10A/div], channel 4: leg 3 current [10A/div]. 
effects on the system such as the FC current ripple increasing. The flow diagram of the FTC has been introduced in Ref. [17].

Within the framework of this research work, each PWM gate control signal is shifted from each other by means of an FPGA board. A VHDL programming code has been implemented on the FPGA board through the Quartus II software. The code uses the first PWM gate control signal (Matlab/ Simulink) as reference, then it creates the missing PWM gate controls signals shifting them correctly compared with the reference. For a healthy mode, the time delay is equal to Ts/3. On the other hand, for a degraded mode, the time delay between two PWM is given by the faulty leg. An accurate knowledge of the faulty leg allows determining the fit time delay. The Table 1 gives the FTC to apply according to the faulty leg. The advantage of this FTC is that it can be fitted whatever the number of legs of interleaved DC/DC converter topologies.

\section{Experimental test bench and results}

\section{Experimental test bench description}

In order to carry out a thorough investigation on the efficiency of the FTC proposed, experimental tests have been carried out between a PEMFC and a 3-leg IBC. The experimental test bench is depicted in Fig. 4. The PEMFC is supplied using hydrogen from tank under pressure, and with clean and dry air from a compressor. In order to supply the Electronic Control Unit (ECU) of the PEMFC with the necessary power to start the FC system, it has to be connected with an external power supply. The IBC topology has a TAMURA L03S050D15 current sensor per leg and an MTX 1032-B voltage sensor at the output for feedback control. The developed Matlab-Simulink control system has been transferred through the real time board dSPACE DS 1104. Additionally, the control of the IBC has been designed so that the PEMFC works in the ohmic region in order to avoid the high and low voltage region for prolonging the PEMFC lifetime [17]. The three PWM gate control signals are generated by a PWM signal generator block provided by dSPACE library in Matlab-Simulink environment. However, these PWM signals are not shifted from each other. In order to guarantee the interleaving concept and to minimize the FC current ripple, the three PWM gate control signals of the three switches (i.e. S1, S2, S3) must be shifted from each other. In the case under study, each PWM gate control signal is shifted from each other with a time delay of Ts/3, where Ts is the switching period of the IBC topology. These three PWM gate control signals are transferred to an Altera Cyclone FPGA board in

Table 1 - FTC to apply according to the faulty leg.

\begin{tabular}{ll}
\hline Faulty leg & \multicolumn{1}{c}{ FTC to apply } \\
\hline Leg 1 & Reconfigure the leg-shift of leg 3 \\
& $(2 \mathrm{Ts} / 3 \rightarrow 5 \mathrm{~T} / 6)$ \\
Leg 2 & Reconfigure the leg-shift of leg 3 \\
& $(2 \mathrm{Ts} / 3 \rightarrow \mathrm{Ts} / 2)$ \\
Leg 3 & Reconfigure the leg-shift of leg 2 \\
& $\left(\mathrm{~T}_{\mathrm{s}} / 3 \rightarrow \mathrm{T}_{\mathrm{s}} / 2\right)$ \\
\hline
\end{tabular}

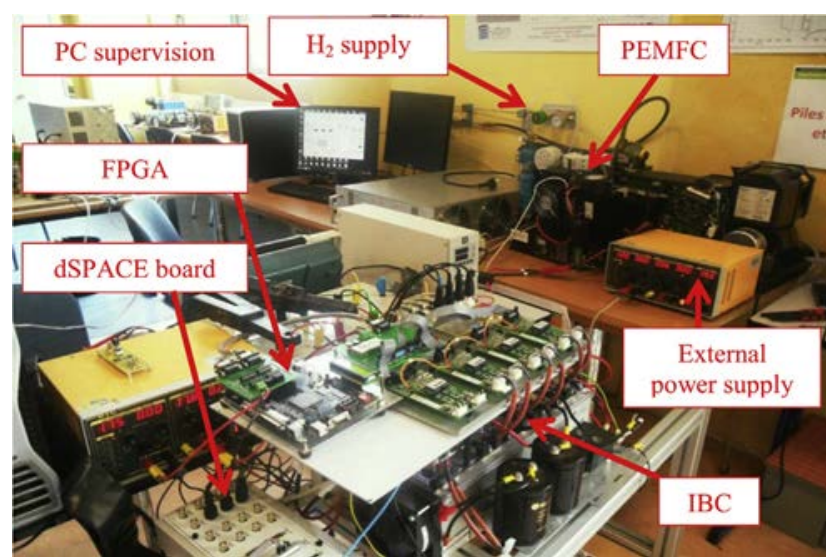

Fig. 4 - Experimental setup carried out for this study.

order to shift them correctly from each other [17]. The system specifications are summarized in Table 2.

In order to simulate an OCF, a failure is introduced in the PWM gate control signals of the power switches using the push-button available on the FPGA board. The FPGA device will see a logic signal ' 0 ' when the push-button is pressed (Fault); whereas the device will see a logic signal ' 1 ' when the push-button is not pressed (no fault). The flow diagram is given in Fig. 5. On the other hand, the push-button can be used to simulate SCFs. In this case, the PWM gate control signal must be forced to " 1 " instead of " 0 " for an OCF.

\section{Experimental results obtained}

Starting from the FTC principle, experimental tests have been performed in the laboratory. The purpose is to show and analyze the effects on FC current ripple applying the proposed FTC. Once the OCF has been detected on the faulty phase, the FTC is applied to the PWM gate control signal through the VHDL programming code implemented on the FPGA board. The results are depicted in Figs. 6, 7.

According to the faulty leg and the Table 1, a fit FTC is applied to the control of the IBC topology. This allows minimizing drastically the fuel cell current ripple and consequently the long-term degradations reported in the literature (Fig. 6). Besides, the application of the FTC does not have impact on the regulation of the DC bus voltage (Fig. 7). It is important to highlight that it is crucial that for specific architectures of FCEV [33], the DC/DC converter provides directly the power to inverters through the DC bus voltage. For this reason, it is essential to provide the constant inverter DC link

Table 2 - System specifications.

\begin{tabular}{ll}
\hline Parameters & Values \\
\hline PEMFC rated power, $\mathrm{P}_{\mathrm{fc}}$ & $1 \mathrm{~kW}$ \\
PEMFC rated current, $\mathrm{i}_{\mathrm{fc}}$ & $42 \mathrm{~A}$ \\
PEMFC current ripple, $\Delta \mathrm{i}_{\mathrm{fc}}$ & $2 \mathrm{~A}$ \\
PEMFC voltage range, $\mathrm{v}_{\mathrm{fc}}$ & $25-32 \mathrm{~V}$ \\
Inductor value, $\mathrm{L}$ & $150 \mu \mathrm{H}$ \\
DC bus voltage, $\mathrm{V}_{\mathrm{dc}}$ & $100 \mathrm{~V}$ \\
Switching frequency, $\mathrm{f}_{\mathrm{s}}$ & $20 \mathrm{kHz}$ \\
Duty cycle range, $\mathrm{D}$ & $0.68-0.74$ \\
\hline
\end{tabular}




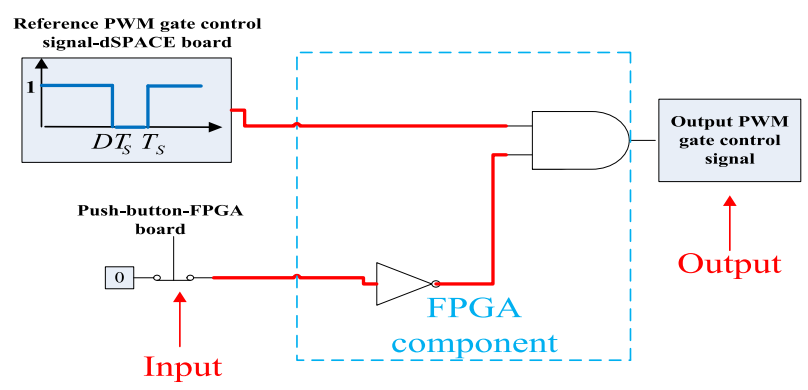

Fig. 5 - Generation of an OCF using the push-button from the FPGA board.

power. Fig. 8 depicts the evolution of FC current ripple expressed as percentage of FC rated current according to the duty cycle. The evolution is focused on three different operating modes such as healthy mode, degraded mode without and with FTC.

It has been suggested in the literature that the FC current ripple should be restricted to less than $10 \%$ of the rated FC stack current $[37,38]$. In our study, the FC current ripple is set to be $5 \%$ of the rated FC current, which means $(\Delta$ ifc $=2 A)$. This restriction is achieved by sizing the three inductors of the IBC topology. As it can be observed in Fig. 8, the FC current ripple value remains lower than the limit of $\Delta$ ifc for a healthy mode. However, for a degraded operating mode without FTC, the FC current ripple remains higher than the limit of $\Delta$ ifc for all values of duty cycle range. On the other hand, applying the FTC, FC current ripple value remains lower than the limit of $\Delta$ ifc.

If another leg was faulty, a fit FTC would be always applied according to the faulty leg and the Table 1. In short, the FTC proposed is efficient and powerful for reducing drastically the fuel cell current ripple whatever the faulty leg.

\section{Discussion}

In order to reduce the high-frequency current ripple, different solutions have been introduced in the literature. The major part of solutions consists in using specific topologies of DC/DC converters or current ripple reduction techniques. Some authors employ conventional current-fed push-pull DC/DC

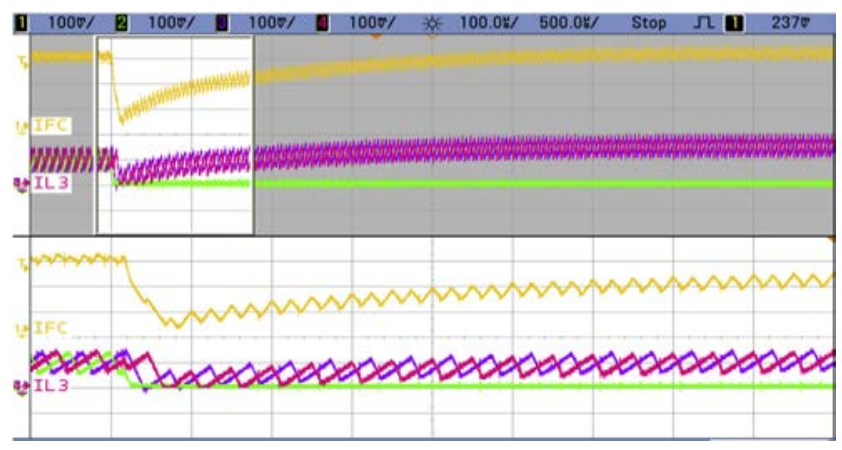

Fig. 6 - Application of the FTC and effect of the FC current ripple: channel 1: FC current [10A/div], channel 2: leg 1 current (faulty) [10A/div], channel 3: leg 2 current [10A/div], channel 4: leg 3 current [10A/div].

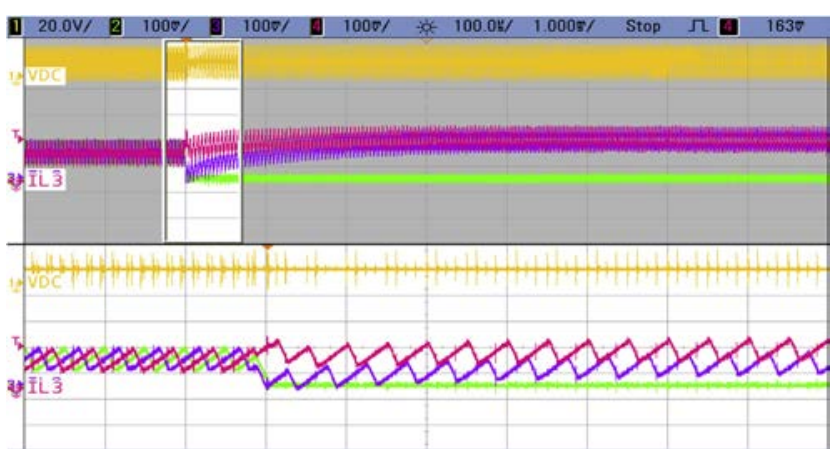

Fig. 7 - Impact on the DC bus voltage once the FTC has been applied: channel 1: DC bus voltage [200 V/div], channel 2: leg 1 current (faulty) [10A/div], channel 3: leg 2 current [10A/div], channel 4: leg 3 current [10A/div].

converters, which are limited for high-frequency applications. The main drawback of this topology is the number of components, which leads up to energy efficiency reduction. Besides, this topology is not fault-tolerant in case of power switch fault. It is important to point out that this topology has the input current ripple switching extremely low at duty cycles around $0.5[35,39]$. On the other hand, other authors use isolated DC/DC converter topologies proposing zero-current switch or zero-voltage switch techniques with input filter in order to increase the switching frequency. Hence, this allows reducing the current ripple rate but the topology contains an isolating transformer [40]. Moreover, other topologies such as half-bridge DC/DC converters can also be considered. Indeed, they are deduced from an IBC topology by introducing a transformer and a diode bridge at its output. However, in order to gain this topology, the duty cycle must be greater than 0.5 and the leakage inductance of the transformer is the main drawback of this topology, which can generate voltage spikes $[41,42]$. Other authors employ coupled inductance in the power converter combined with a hybrid filter. However, a thorough design of the coupled inductance is crucial [43]. IBC and Floating Interleaved DC/DC Boost Converter (FIBC) topologies are also considered in the literature $[17,34,44]$, to minimize the high-frequency current ripple. In Ref. [45], the authors propose a zero input current ripple boost converter by using a mirror ripple circuit. In order to avoid circulating current, a capacitor bank is inserted between the mirror ripple and the output of the boost converter. This technique presents the drawback to be only efficient in steady state and under

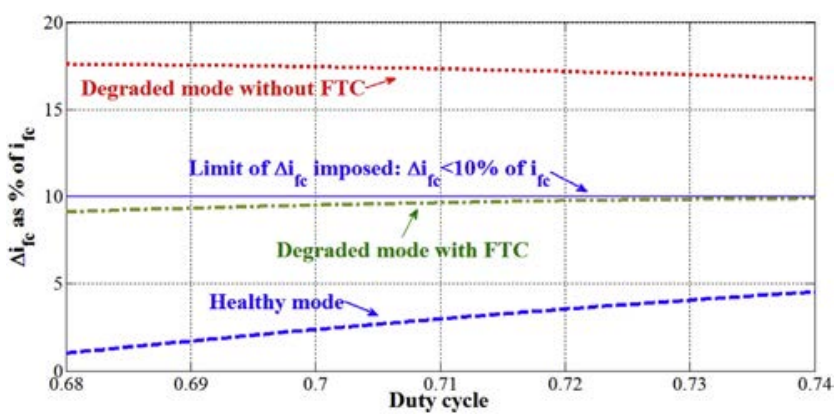

Fig. $8-\Delta$ ifc as percentage of ifc according to the duty cycle. 


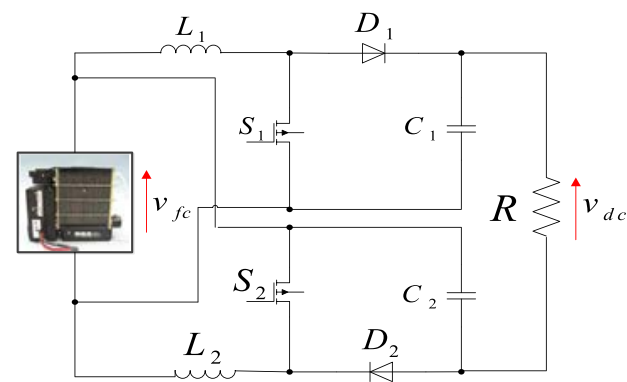

Fig. 9 - Architecture of a 2-leg FIBC.

Continuous Conduction Mode (CCM). In Ref. [46], the authors propose an active filtering method to actively damp the current ripples generated by DC/DC converters. However, such a solution increases the system components and complexity which is not fit for automotive applications. A second order low pass filter is proposed in Ref. [47] in order to minimize the current ripple generated by a FIBC. However, the passive components have been sized to filter the high-frequency current ripple for a healthy mode (i.e. no power switch faults). Consequently, the proposed second order low pass filter would not be efficient if one of the legs was faulty due to the drastic increasing of current ripple [48]. Finally, in Ref. [49], the authors propose a two-leg IBC with current ripple cancellation whatever the desired duty cycle value without increasing the number of components. This architecture presents a main drawback in terms of fault-tolerance despite the presence of static redundancy. Indeed, if one of the legs was faulty, this architecture would lose its advantage of the current ripple cancellation. The same architecture could be developed into a four-leg IBC in order to cancel current ripple in case of power switch faults, but this would go back to increase the complexity and cost of the converter.

The main contribution of this paper compared to other research papers presented above, is the development for interleaved converter topologies of an FTC without adding additional components to reduce drastically the current ripple in case of operating degraded mode (i.e. loss of one leg). This FTC is implemented on a FPGA board, which over the last years has demonstrated high performances for many power electronic applications $[9,14]$. An other crucial research work is remaining for interleaved DC/DC converter topologies, namely the reliability of the latter in case of power switch faults.

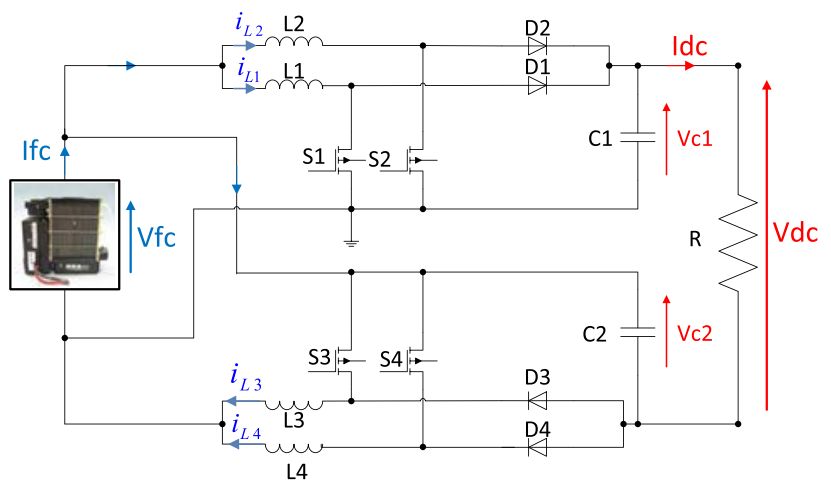

Fig. 10 - Architecture of a 4-leg FIBC.
Indeed, as it has been demonstrated in this paper, the current of the healthy legs increase of $50 \%$ compared to a healthy mode in case of the loss of one leg, creating consequently additional electrical and thermal stresses. For specific interleaved converter topologies (e.g. FIBC), the electrical stresses are higher than an IBC topology. The interleaving concept of this topology is guaranteed by the parallel connection of the non-floating and floating version of the boost converter (Fig. 9) [48]. The number of legs of this topology must be necessarily pair in order to keep a balance between the non-floating part (i.e. upper part) and the floating part (i.e. lower part). Generally, a four-leg FIBC (Fig. 10) is preferred for fault-tolerance purpose since a power switch fault in a 2-leg FIBC will lead up to an unsteadiness between the non-floating and floating part. On the other hand, the loss of one leg located either in a nonfloating or floating part for a four-leg FIBC, could be compensated by the other leg located in the faulty part. Despite the FIBC keeps the balance between the two parts, this leads up to the overload of a leg, creating consequently more additional electrical and thermal stresses (i.e. the current of the healthy leg increase of $100 \%$ compared to a healthy mode) on power switches and inductive components. In summary, critical cases of operating degraded mode must be avoided by developing efficient FTC in order to guarantee the reliability of the converter in case of power switch faults.

\section{Conclusion}

The main purpose of this paper was to present a FPGA based fault-tolerant control of an interleaved DC/DC boost converter for fuel cell electric vehicles. Basing on a thorough bibliographical study, it was shown that power switches ranked the most delicate components in DC/DC converters. In this paper, open-circuit faults have been investigated. The loss of one leg in case of open-circuit fault leads up to the drastic increase of the fuel cell current ripple, responsible to long-term degradations on the fuel cell. In order to minimize the undesirable effects on the fuel cell, a fault-tolerant control without using additional components is applied to the interleaved DC/DC converter topology when the fault has been detected on the faulty leg. The fault-tolerant control consists in modifying the PWM gate control signals according to the faulty leg. The results obtained by experimental tests have demonstrated that the FC current ripple decreases drastically compared with a degraded operating mode without applying a fault-tolerant control. The current ripple reduction allows improving the fuel cell performance while reducing hydrogen consumption and optimizing its lifetime. In order to guarantee the reliability of the interleaved DC/DC boost converter in case of power switch faults, a fault-tolerant control consisting in acting on the control of the latter will be implemented on a FPGA board.

\section{R E F E R E N C E S}

[1] Yang S, Bryant A, Mawby P, Xiang D, Li R, Tavner P. An industry-based survey of reliability in power electronic converters. IEEE Trans Ind Appl May 2011;47(3):1441-51. 
[2] Ribeiro E, Marques Cardoso AJ, Boccaletti C. Fault tolerant strategy for a photovoltaic DC $\backslash$ DC converter. IEEE Trans Power Electron 2013;28(6):3008-18.

[3] Pei X, Nie S, Chen Y, Kang Y. Open-circuit fault diagnosis and fault-tolerant strategies for full-bridge DC-DC converters. IEEE Trans Power Electron 2012;27(5):2550-65.

[4] Ambusaidi K, Pickert V, Zahawi B. New circuit topology for fault tolerant H-bridge DC-DC converter. IEEE Trans Power Electron 2010;25(6):1509-16.

[5] Jung MJ, Park SE, Oh SU, Lee HJ, Seong SJ. Fault detection and isolation of two DC-DC converters parallel operation with single CT. Proc IEEE Int Symposium Industrial Electron 2001;2:1060-5.

[6] Pei X, Nie S, Kang Y. Switch short-circuit fault diagnosis and remedial strategy for full-bridge DC-DC converters. IEEE Transaction Power Electron 2015;30(2):996-1004.

[7] Jamshidpour E, Shahbazi M, Poure P, Gholipour E, Saadate S. Fault tolerant operation of single-ended non-isolated DC-DC converters under open and short-circuit switch faults. In Proceedings 15th European conference on power electronics and applications (EPE); 2013. p. 1-7.

[8] Jamshidpour E, Poure P, Gholipour E, Saadate S. Singleswitch DC-DC converter with fault-tolerant capability under open-and short-circuit switch failures. IEEE Trans Power Electron 2015;30(5):2703-12.

[9] Jamshidpour E, Shahbazi M, Saadate S, Poure P, Gholipour E. FPGA based fault detection and fault tolerance operation in DC-DC converters. In: Proceedings of IEEE International symposium on power electronics, electrical drives, automation and motion (SPEEDAM); 2014. p. 37-42.

[10] Park T, Kim T. Novel fault tolerant power conversion system for hybrid electric vehicles. Proc IEEE Veh Power Propuls Conf (VPPC) 2011:1-6.

[11] Fatah B, Hamed Y, Chokri M, Naceur H, Hassan H. Faults detection and isolation for energy management system in electric traction. In: Proceedings of International conference on electrical engineering and software applications (ICEESA); 2013. p. 1-6.

[12] Park K, Chen Z. Open-circuit fault detection and tolerant operation for a parallel-connected SAB dc-dc converter. In: Proceedings of the twenty-ninth IEEE applied power electronics conference and exposition (APEC); March 2014. p. $1966-72$.

[13] Choudhary V, Ledezma E, Ayyanar R, Button RM. Fault tolerant circuit topology and control method for input-series and output-parallel modular DC-DC converters. IEEE Trans Power Electron 2008;23(1):402-11.

[14] Shahbazi M, Jamshidpour E, Poure P, Saadate S, Zolghadri M. Open fault diagnosis for non-isolated DC-DC converters using field programmable gate array. IEEE Trans Industrial Electron Sept. 2013;60(9):4136-46.

[15] Karimi S, Gaillard A, Poure P, Saadate S. Current sensor faulttolerant control for WECS with DFIG. IEEE Trans Industrial Electron November 2009;56(11):4660-70.

[16] IEEE Xplore Digital Library. available online, http:// ieeexplore.ieee.org/Xplore/home.jsp; March 2015.

[17] Guilbert D, Gaillard A, Mohammadi A, N'Diaye A, Djerdir A. Investigation of the interactions between proton exchange membrane fuel cell and interleaved DC/DC boost converter in case of power switch faults. Int J Hydrog Energy 2015;40(1):519-37.

[18] De Bernardinis A, Coquery G. First approach for a fault tolerant power converter interface for multi-stack PEM fuel cell generator in transportation systems. In: Proceedings of 13th power electronics and motion control conference; 2008. p. 2192-9.

[19] Candusso D, De Bernardinis A, Péra MC, Harel F, François X, Hissel D, et al. Fuel cell operation under degraded operating modes and study of diode by-pass circuit dedicated to multistack association. Energy Convers Manag April 2008;49(4):880-95.

[20] De Bernardinis A, Candusso D, Harel F, François X, Coquery G. Experiments of a 20 cell PEFC operating under fault conditions with diode by-pass circuit for uninterrupted power delivery. Energy Convers Manag May 2010;51(5):1044-54.

[21] Xu L, Li J, Ouyang M, Hua J, Li X. Active fault tolerance control system of fuel cell hybrid city bus. Int J Hydrog Energy November 2010;35(22):12510-20.

[22] Marx N, Boulon L, Gustin F, Hissel D, Agbossou K. A review of multi-stack and modular fuel cell systems: interests, application areas and on-going research activities. Int J Hydrog Energy August 2014;39(23):12101-11.

[23] Riascos LAM, Cozman FG, Miyagi PE, Simoes MG. Bayesian network supervision on fault tolerant fuel cells. In: Proceedings of 41st IAS annual meeting of industry applications conference; 2006. p. 1059-66.

[24] Feng Z, Zhong Z. A Systematic approach of improving a fault tolerant fuel cell bus powertrain safety level. In: Proceedings of IEEE international conference on vehicular electronics and safety (ICVES); 2006. p. 73-7.

[25] Puig V, Rosich A, Ocampo-Martinez C, Sarrate R. Faulttolerant explicit MPC of PEM fuel cells. In: Proceedings of the 46th IEEE conference on decision and control; 2007. p. 2657-62.

[26] Palma L, Enjeti PN. A modular fuel cell, modular DC-DC converter concept for high performance and enhanced reliability. IEEE Trans Power Electron June 2009;24(6):1437-43.

[27] De Bernardinis A, Candusso D, Harel F, Coquery G. Power electronics interface for an hybrid PEMFC generating system with fault management strategies for transportation. In: Proceedings of 13th European conference on power electronics and applications (EPE'09); 2009. p. 1-10.

[28] Sun Y, Ghantasala S, El-Farra NH. Monitoring and faulttolerant control of distributed power generation: application to solid oxide fuel cells. In: Proceedings of american control conference (ACC); 2010. p. 448-53.

[29] Bianchi FD, Ocampo-Martinez C, Kunusch C, SanchezPena RS. Fault-tolerant unfalsified control for PEM fuel cell systems. IEEE Trans Energy Convers 2015;30(1):1-9.

[30] Wahdame B, Girardot L, Hissel D, Harel F, François X, Candusso D, et al. Impact of power converter current ripple on the durability of a fuel cell stack. In: Proceedings IEEE international symposium on industrial electronics (ISIE'08); 2008. p. 1495-500.

[31] Gerard M, Poirot-Crouzevier JP, Hissel D, Pera MC. Ripple current effects on PEMFC aging test by experimental and Modeling. J Fuel Cell Sci Technol April 2011;8:1-5.

[32] Rallieres O. Modélisation et caractérisation de Piles à Combustible et Electrolyseurs PEM [Ph. D. thesis]. France: Université de Toulouse; November 2011.

[33] Dawei G, Zhenhua J, Qingchun L. Performance comparison of different fuel cell vehicle power trains. In: Proceedings of IEEE vehicle power and propulsion conference (VPPC'08); 2008. p. 1-5.

[34] Kabalo M, Blunier B, Bouquain D, Miraoui A. State-of-the-art of DC/DC converters for fuel cell vehicles. In: Proceedings of IEEE vehicle power and propulsion conference (VPPC'10), Lille; 2010. p. 1-6.

[35] Fontes G, Turpin C, Astier S, Meynard T. Interactions between fuel cell and power converters: influence of current harmonics on a fuel cell stack. IEEE Trans Power Electron 2007;22(2):670-8.

[36] DOE. Hydrogen, fuel cells and infrastructure technologies program, multi-year research, development and 
demonstration plan, U.S department of energy. available online, http://www1.eere.energy.gov/hydrogenandfuelcells/ mypp/pdfs/fuel_cells.pdf; March 2012.

[37] Lai J.S., Liu C., Ridenour A., Multiphase soft switched dc/dc converter and active control technique for fuel cell ripple current elimination, April 14 2009, US Patent 7,518,886.

[38] Testa A, De Caro S, Caniglia D, Antonucci V, Ferraro M, Sergi F. Compensation of the low frequency current ripple in single phase grid connected fuel cell power systems. In: Proceedings of the 13th European conference on power electronics and applications (EPE'09); 2009. p. 1-10.

[39] Kwon JM, Eung-Ho K, Kwon BH, Nam KH. High efficiency fuel cell power conditioning system with input current ripple reduction. IEEE Trans Industrial Electron 2009;56(3):826-34.

[40] Sanchis-Kilders E, Ejea JB, Ferreres A, Maset E, Esteve V, Jordan J, et al. Bidirectional coupled inductors step-up converter for battery discharging-charging. In: Proceedings of IEEE 36th power electronics specialists conference (PESC'05); 2005. p. 64-8.

[41] Andersen RL, Barbi I. A three-phase current-fed push-pull DC-DC Converter. IEEE Trans Power Electron 2009;24(2):358-68.

[42] Lembeye Y, Bang VD, Lefevre G, Ferrieux JP. Novel half-bridge inductive DC-DC isolated converters for fuel cell applications. IEEE Trans Energy Convers 2009;24(1):203-10.

[43] Ostroznik S, Bajec P, Zajec P. A study of a hybrid filter. IEEE Trans Industrial Electron 2009;57(3):935-42.
[44] Mazumder SK, Burra RK, Acharya K. A ripple-mitigating and energy-efficient fuel cell power-conditioning system. IEEE Trans Power Electron 2007;22(4):1437-52.

[45] Pan CT, Liang SK, Lai CM. A zero input current ripple boost converter for fuel cell applications by using a mirror ripple circuit. In: Proceedings of IEEE 6th international power electronics and motion control conference (IPEMC); 2009. p. 787-93.

[46] Shahin A, Gavagsaz-Ghoachani R, Martin JP, Pierfederici S, Davat B, Meibody-Tabar F. New method to filter HF current ripple generated by current-fed DC/DC converters. IEEE Trans Power Electron 2011;26(12):3832-42.

[47] Kabalo M. Conception et Réalisation de Convertisseur DC-DC pour une Chaîne de Traction Electrique et/ou Hybride [Ph. D. thesis]. France: University of Technology of BelfortMontbeliard (UTBM); December 2012.

[48] Guilbert D, Mohammadi A, Gaillard A, N'diaye A, Djerdir A. Interactions between fuel cell and DC/DC converter for fuel cell electric vehicle applications: Influence of faults. In: Proceedings of the 39th annual conference of the IEEE industrial electronics society (IECON); 2013. p. 912-7.

[49] Rosas-Caro JC, Valdez-Resendiz JE, Mayo-Maldonado JC, Salas-Cabrera R, Ramirez-Arredondo JM, Salome-Baylon J. Interleaved power converter with current ripple cancelation at a selectable duty cycle. In: Proceedings of IEEE energy conversion congress and exposition (ECCE); 2011. p. 122-6. 